\title{
頸部交通外傷の MRIによる検討
}

\author{
諸岡整形外病院 \\ 諸 岡 正 明・西 崎 博 己

\section{Magnetic Resonance Imaging for Traffic-accident Injuries of the Cervical Spine} \\ by \\ Masaaki Morooka and Hiromi Nishizaki \\ Morooka Orthopedic Hospital, Fukuoka, Japan
}

\begin{abstract}
Ninety-three patients with cervical injuries by traffic accidents, 67 patients with cervical radiculopathy and 56 control adults were examined by MRI. Numbers and levels of affected discs were investigated on a sagittal view, and direction of disc herniations on a transverse view. MRI findings were compared with plain X-ray findings. Much more affected discs were observed by MRI than by X-ray examination, especially in the cases of traffic injury. In most cases, affected levels revealed by MRI were not coincident with those found in $\mathrm{X}$-ray. It was suggested that narrow discs observed in X-ray were already low activity level, so it is not liable to be injured now.

A majority of herniated discs were directed toward midline or near midline. It is supposed that these central herniations seldom manifest objective signs and, therefore, that it is difficult to identify the attributable level in the cervical spinal injuries without MRI.
\end{abstract}

はじめに

脊椎疾患に対する MRI の有用性は,すでに確立され， さらに，この装置を用いて，種々の疾患の病因，病態 の解明が期待されている ${ }^{12233)}$.

われわれは，この装置を用いて，他覚的に異常所見 をとらえることが困難とされている頸部交通外傷につ いて，検討し $2 ， 3$ の知見を得たので報告する.

\section{対象および方法}

昭和 63 年 7 月より平成元年 4 月までに, MRI を施行 した.受傷後 30 日以上症状がつづいた頸部の交通外傷 患者 93 名を, 追突により受傷した群 (42 名) と衝突な ぞ追突事故以外で受傷した群（51名）に別け，対照と して, 頸部の椎間板へルニアおよび根症の群 (67 名) (頸 椎症群とする）と当病院の職員群（56 名）に別けて検 討した。職員群には現在および過去に頸部の症状など あった人も含めた（表 1 ).

使用装置は，日立 MRP-20-1 (22 例)，日立 G-50 (191
例）使用し, SR 法にて SIice 厚 $0.5 \mathrm{~cm}$ で, 矢状断面 像にて，椎間板へルニアの有無を，またへルニアの有 った部位にて横断面で,ヘルニアの脱出方向を調べた。 交通外傷患者の 89 例, 顓椎症の 61 例では頸部 X 線 所見との対比検討を行った（表 2 ）.

表 1 症例

\begin{tabular}{|c|c|c|c|}
\hline & 人数 & 性 別 & $\begin{array}{l}\text { 平均 } \\
\text { 年令 }\end{array}$ \\
\hline 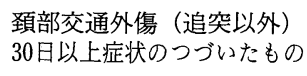 & 51 & 어 23 우 28 & 36.4 \\
\hline $\begin{array}{l}\text { 追突による交通外傷 } \\
\text { 30日以上症状のつづいたもの }\end{array}$ & 42 & 궁 28 우 14 & 36.5 \\
\hline ヘルニア及根症 & 67 & 万) 41 우 26 & 48.1 \\
\hline 対照（当院職員） & 56 & 구 14 우 42 & 31.5 \\
\hline 計 & 216 & 万'106 우110 & 38.6 \\
\hline
\end{tabular}

*1988年 7 月より 1989 年 4 月までの検査例 


\begin{tabular}{|c|c|c|}
\hline & 矢 状 面 像 & 213例 \\
\hline $\begin{array}{l}\text { SR 法 } \\
\text { に }\end{array}$ & $\begin{array}{l}\text { 横断面像 対照者を除 } \\
\text { いた疾病群のへルニア } \\
\text { のあった椎間で検討 }\end{array}$ & $\begin{array}{l}336 \text { 椎間板中判定が } \\
\text { 可能だった275椎間板 } \\
\text { で検討 }\end{array}$ \\
\hline \multicolumn{2}{|c|}{$\begin{array}{l}\text { 単純X線写真の左右像で } \\
\text { (対照例56例は除外) }\end{array}$} & $\begin{array}{l}150 \text { 例 } \\
\text { 事故（追突以外）89例 } \\
\text { 頝椎症 61例 }\end{array}$ \\
\hline
\end{tabular}

表 3 年令層別ヘルニア数 (平均)

\begin{tabular}{c|c|c|c|c}
\hline \hline & 対 照 & $\begin{array}{c}\text { 事 故 } \\
\text { (追突以外) }\end{array}$ & 追 突 & 頝椎症 \\
\hline$\sim 30 才$ & 0.3 & 0.9 & 1.0 & 1.6 \\
\hline $31 \sim 50 才$ & 0.6 & 1.7 & 2.3 & 2.5 \\
\hline 50 才 & 1.5 & 3.2 & 3.0 & 2.6 \\
\hline Total & 0.5 & 1.7 & 2.0 & 2.5 \\
\hline
\end{tabular}

\section{結果}

1. 矢状面像で，年令層を 30 才以下 $31 \sim 50$ 才， 51 才以上の 3 段階に別け， 1 人当りのヘルニア数を調べ た. 30 才以下では, 事故群で約 1 力月, 頸椎症で 1.6 カ月, 職員でも 0.3 カ月のへルニアがあり, 年令とと もに増加し, 51 才以上では, 事故群, 頸部症で 1.6 力 月〜 3.2 力月の脱出がみられ, 職員群でも 1.5 力月の脱 出があった（表 3 ).

2. 各群別に椎間板罹患率を調べた.

事故群では, 74〜83\%が，1 カ月以上の椎間板が䍜患 しているのに比して, 頸椎症では $95.5 \%$ とほとんどが MRI で罹患が発見された。職員群でも $28.6 \%$ の䍜患率 であった(図 1)。一方X線写真上の罹患率は, 著明に 下がり, 事故群で $37 \sim 39 \%$, 頸椎症で $78.7 \%$ であっ た（図 2 ).

罹患のあった例の罹患椎間板数は, 単椎䍙患は以外 に少なく, 頸椎症で. $8.7 \%$, 事故群で $28.6 \%$ 37.0\% が I 椎間板のみで, 職員群でも半数以上が複数罪患で あった(図 3 )。

平均で職員群 1.4 椎間, 事故頸椎症では, $2.2 \sim 2.6$ \%椎間であった。

一方 X線写真では, MRI の場合より I 椎間眻患の率 が高くなり, 事故, 頸椎症で平均 1.6 2.5 椎間の罹患 であった (図 4).

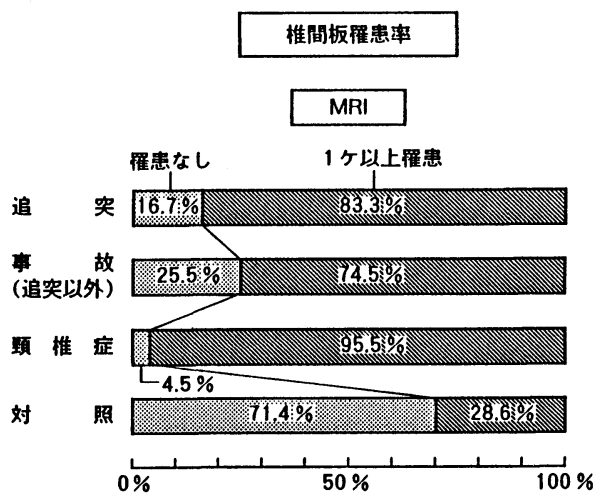

図 1 椎間板罹患率 MRI

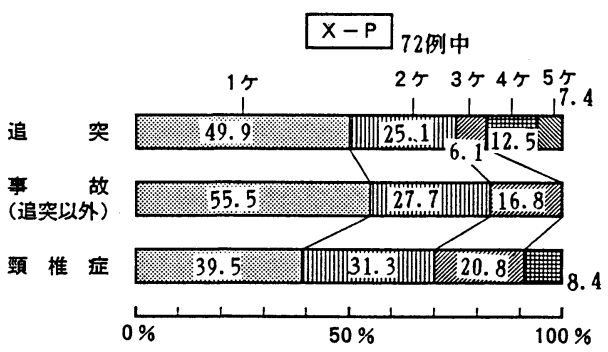

図 2 椎間板罹患率 $\mathrm{X}-\mathrm{P}$

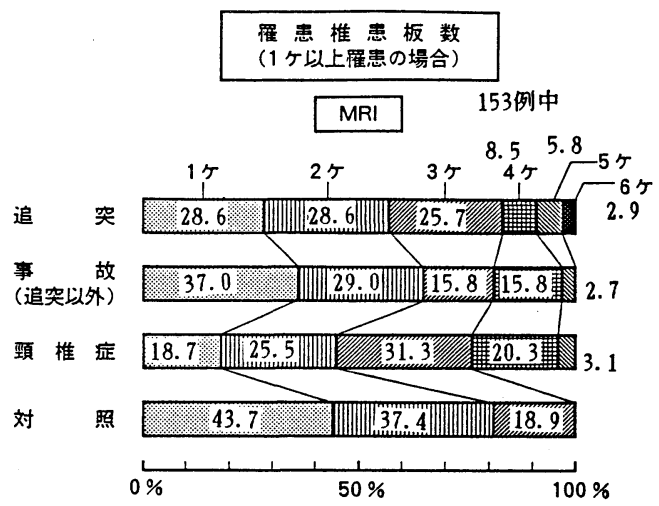

図 3 罹患椎患板数（1 カ以上罪患の場合） MRI

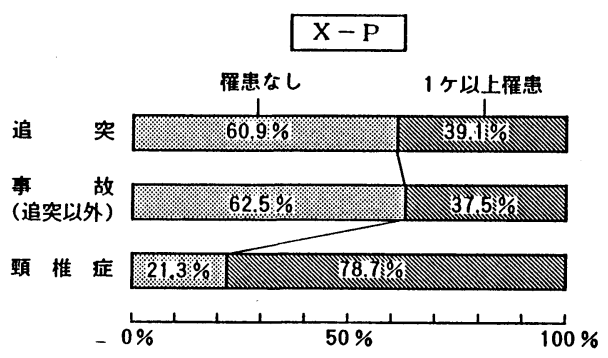

図 4 罹患椎患板数（1 カ以上罹患の場合） X-P 


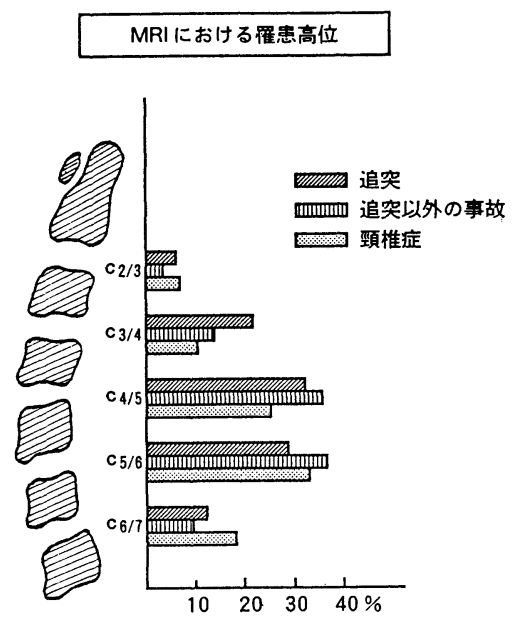

图 5 MRIにおける罹患高位

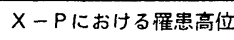

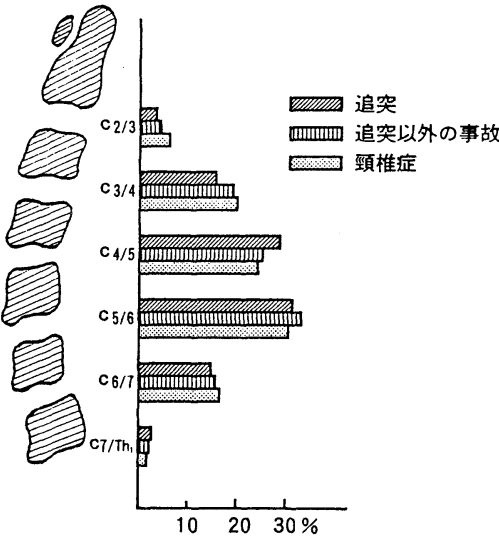

図 6 X-P における罹患高位

3. 各高位別椎間板䍜患頻度を疾患群別, X線写真 上, MRI 上比較検討したが, C4-5 C5-6 で, 高頻度で, ついで C3-4 と C6-7 で罹患しやすいパターンはいずれ の場合も変わらなかった（図 5 , 図 6 ).

4. MRIで異常を認めた 137 例についてX線写真で の異常部位との相関を調べた. その結果事故群の半数 以上の 55〜 57 \%でX線上異常なく, X 線上の異常部位 が MRI での異常部位と異なる例を含めると, 66〜 68\% でX線写真で異常のない部位に MRI でヘルニアが発見 された。

頸椎症ではこの両方で $25 \%$ \%゙った. MRI の異常部 位とX線写真での異常部位が一致する場合は, 事故群 で 10〜17\%頸椎症で 17 \%と低い割合であった(図 7 ).

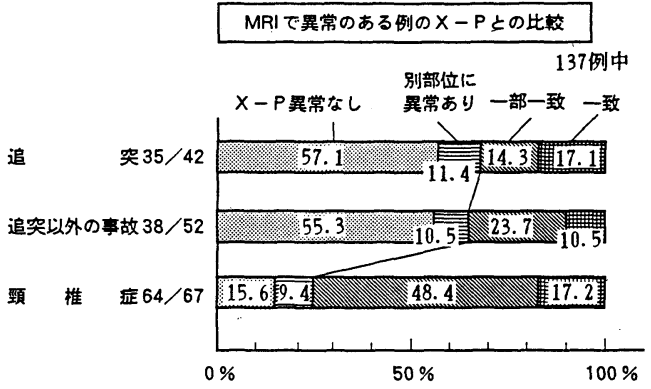

図 $7 \mathrm{MRI}$ で異常のある例の X-P との比較

$$
\text { ヘルニフ発生部位 }
$$
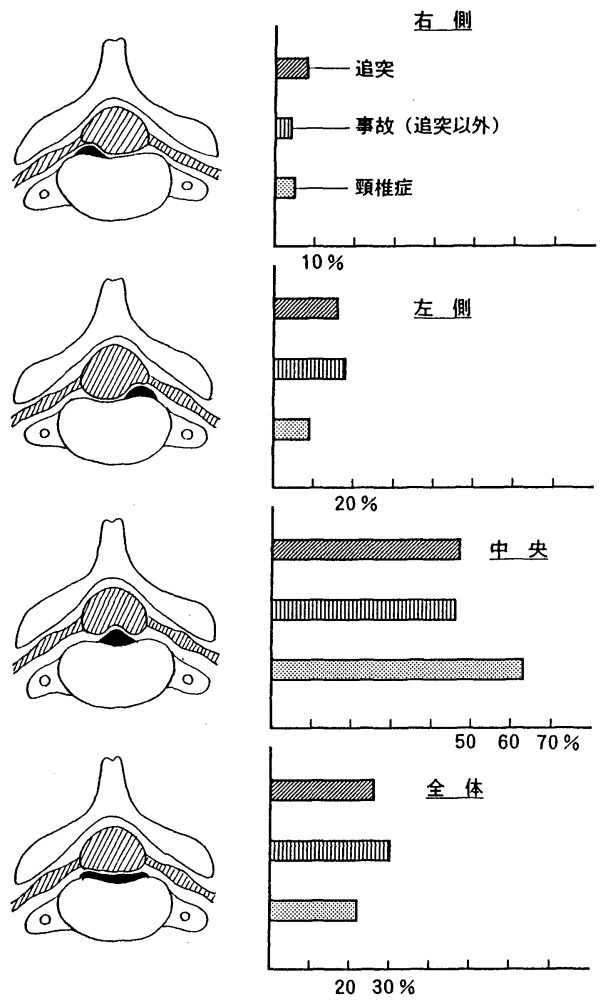

図8ヘルニア発生部位

5. MRI で異常を認めた 336 椎間で横断像をとり, 髄核の脱出方向が読影可能であった 275 椎間について, その脱出方向を中 (正中), 右, 左，および全 (正中よ り左右両方向に広がっているもの）に別けて調べた。

その結果, 各群とも中心性のものが圧倒的に多く, 全体的に膨隆している例を含めると, $80 \%$ 近くを占め た. 側方に出る率は, 15〜25\%で, どの群でも左側の 
方が多かった（図 8 ）。

\section{考察}

MRI は脊椎疾患では, 骨の影響を受けず, 任意の方 向の断面の像が得られ椎間板や勒帯，脊髄など軟部の 状態が観察出来，生体に無浸収，無障害であることを 合わせると，他の補助診断法に比して，格段に優れた 補助診断法であることは言を待たな(24556677.

一方頑固で，さまざまな愁訴を有するわりに，他覚 的に異常所見をとらえることが難しいといわれている 頸部交通外傷に対して, かならずしも正確な病態が把 握されているとはいえない。

この疾患に対し, われわれは, MRI を用いて椎間板 の脱出に的をしぽり検索を行い, 若干の検討を加えた。 その結果, 各疾患群, 対照群とも, X線写真でとらえ られた，椎間板異常より多い個所で，しかもかなり高 率に，X線で異常のあるところと別の高位で，椎間板 の脱出があることがわかった。その率は，事故群では 著しく高率であった。このことは，症状をともなった 新らしい椎間板損傷が，X線写真上狭少化を来してく るまでには，相当の期間を要し，X線上狭少化を来し てきた部位は, 症状が発現しにくいことが推定される。

今回は臨床症状との関連については，まとめ得てい ないが，MRIでの髄核の脱出が，かならずしも症状を ともなうものでないことは, 職員群の例や, 症状のな くなってきた人の MRI でもへルニアのあることでわか る、へルニアがいつの時点で, またどの程度で症状が あり, どう変化していくのかは, 今後の研究課題であ ろう。

事故群と頸椎症との MRI とX線での異常発現率が, 事故群で著しい差があったのに比して，頸椎症ではそ の差が少なかったことは，事故は正常者の多い対象群 におこるという疾病発生の母集団の違いによるもので あろうことが考えられる.事故群を追突によるものと， その他の受傷機転の違いにより検討を加えたが，今回 までの有意の言及を加え難い。職員例 55 例は, 職場の
性格上女性で，しかも若年者が多く，しかも過去およ び現在の肩こり, 頸部痛など有症状者を含んでいる点, 対照群として問題を残している．横断像で調べ得たへ ルニアの脱出部で, 圧倒的に中心性が多かったことは, 頸部の疾患が, 神経学的に異常所見としてとらえ難く, 高位診断がむつかしい一つの理由ではないかと考えた。

今回の調査では，まだ症例が少なく，事故の発生機 転別の知見を得ることが出来なかった。また，追跡期 間も短いため, MRI で認めた, 椎間板の異常の経時的 変化を知ることが出来なかった．今後はさらに, 症例 数を増やし, 臨床症状臨床所見とも合わせ検討を試み たい。

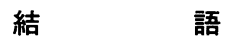

1. MRI は, X線写真と比べ, 椎間板の異常を発見 する率が高く，とくに事故群で著しかった。

2. MRI で異常のあった部位の, X線所見との一致 率は低く, X線異常を認めない部位での症状発現が多 いことが示唆された。

3. 横断像で中心性のヘルニアが圧倒的に多く, 高 位診断がむつかしく, 他覚的所に乏しい原因の一つか と推察された。

\section{参 考 文 献}

1）有薏 剛・他：脊椎疾患におけるMRIの応用, 西日本 脊椎研究会誌, 14, 330-333, 1988.

2）星野雄一・他：脊椎外科におけるMRIの有用性，臨整 外, $21,451-459,1986$.

3）李 元浩・他：春椎, 脊髄疾患におけるMRIの診断的 価值について，臨整外，21，461-468，1986。

4）松田芳郎・他：頝椎部MRIの進歩と限界, 西日本脊椎 研究会誌，14，342-345，1988.

5）宮坂和男 - 他: 春椎, 椎間板病変のMRI, 日独医報, 33, 563-574, 1989.

6）村尾 哲·他：脊椎疾患のMRIによる検討, 西日本脊 椎研究会誌, 14, 334-337, 1988.

7） 竹本和雅·他：椎体椎間板のMRI, 日独医報, 33, 563 $-574,1985$. 